\title{
Large-Scale Copy-Number Alterations in Chicken Ovarian Cancer
}

\author{
Hee Won Seo ${ }^{1}$, Jin Won Choi ${ }^{1}$, Tae Won Yun ${ }^{1}$, Hong Jo Lee ${ }^{1}$, Hee Seung Kim², Yong Sang Song ${ }^{2}$, Gwonhwa Song ${ }^{1}$ \\ and Jae Yong $\operatorname{Han}^{1 *}$ \\ ${ }^{1}$ WCU Biomodulation Major, Department of Agricultural Biotechnology, and Research Institute for Agriculture \\ and Life Sciences, 599 Gwanak-ro, Gwanak-gu, \\ ${ }^{2}$ College of Medicine, Yeongeon-dong, jongro-gu, Seoul National University, Seoul, Korea
}

\begin{abstract}
Copy-number variation (CNV) in particular genomic segments owing to deletions or duplications can induce changes in cellular gene expression patterns and may increase susceptibility to diseases such as cancer. The aim of this study was to examine CNVs related to the incidence of epithelial ovarian cancer in chickens. Genomic DNA was extracted from blood cells and cancerous ovaries collected from four 120-week-old White Leghorn chickens and were used for array-based comparative genome hybridization (CGH) analysis. As a result, 25 amplified and 10 deleted CNV regions were detected in chicken ovarian cancer. Of these, 10 amplified and two deleted CNV regions contained genes associated with human ovarian cancer. Our study using a chicken model may provide a better understanding of human epithelial ovarian cancer.
\end{abstract}

(Key words : Array CGH, Chicken, Copy number variation, Ovarian cancer)

\section{INTRODUCTION}

Ovarian cancer is the sixth most common cancer in women (Kim et al., 2007), and it is estimated that approximately 22,000 new cases of ovarian cancer will be diagnosed annually in the United States, and that about $70 \%$ of patients with ovarian cancer will die of the disease (Jackson et al., 2007). Owing to its high lethality, ovarian cancer continues to be an important focus of research on gynecological diseases. Ovarian cancer is often not diagnosed until it has reached an advanced stage, contributing to its high lethality. In addition, effective prevention methods are not currently available because of a poor understanding of the disease (Rodriguez-Burford et al., 2001).

Studies on human ovarian cancer have been hampered by the lack of an appropriate animal model. Although mouse models have been widely used for research on many human diseases, a mouse model is not suitable for studying human ovarian cancer. In mice, ovarian tumors are derived mainly from granulosa or ovarian germ cells, and few ovarian cancers are spontaneously derived from the epithelial region of the mouse ovary (Vanderhyden et al., 2003). In contrast, approximately $90 \%$ of human ovarian cancers are thought to originate from the ovarian surface epithelium (Orsulic, 2004). The laying hen provides a good animal model of human ovarian epithelial cancer because of the physiological and genetic similarities between ovarian cancer in humans and chickens. As in human ovarian cancer, chicken ovarian cancer spontaneously develops from the epithelial region of the ovary (Johnson, 2009), and the development of chicken reproductive disorders including ovarian cancer is dependent on age (Fredrickson, 1987; Seo et al., 2009). Furthermore, ovarian tumors in both humans and chickens share several molecular commonalities (Ahn et al., 2010) for example, a human ovarian cancer diagnostic marker, cell surface associated mucin 16 (MUC16), also known as CA125 (Jackson et al., 2007), and the histological markers v-erbb2erythroblastic leukemia viral oncogene homolog 2 (ERBB2) and proliferating cell nuclear antigen (PCNA) (RodriguezBurford et al., 2001) were detected in chicken ovarian adenocarcinoma. These similarities make chicken ovarian cancer a useful and accurate model for human epithelial ovarian cancer.

Although several factors influence tumor development, genetic disorders such as DNA copy-number differences are strongly correlated with cancer predisposition (Shlien and

\footnotetext{
* Corresponding author: Jae Yong Han, Ph.D., WCU Biomodulation Major, Department of Agricultural Biotechnology, Seoul National University, 599 Gwanak-ro, Gwanak-gu, Seoul 151-921, Korea. Tel: 82-2-880-4810; Fax: 82-2-874-4811; E-mail: jaehan@snu.ac.kr
} 
Malkin, 2009). Duplication and deletion of human chromosomal segments are examples of the extensive polymorphism called copy number variation (CNV). Despite the strong potential for CNVs, initial studies have had difficulty in detecting CNVs smaller than a megabase because of low resolution ( $\sim 1$ megabase). Recently, the use of high-resolution comparative genome hybridization (CGH) has overcome many of these limitations, making high-throughput analysis of $\mathrm{CNV}$ available for cancer research and prevention. Certain CNVs have been reported to be related to predisposition, incidence, and progression of specific human diseases (Hastings et al., 2009). For example, uncommon copy numbers of the genes tumor protein p53(TP53), retinoblastoma 1(RB1), and phosphatase and tensin homolog (PTEN) are related to cancer development and etiology (Shlien and Malkin, 2009). Frequent duplications of genes such as fibroblast growth factor 3/4 (FGF3/4), fibroblast growth factor receptor 1 (FGFR1), cyclin E1(CCNE1), p21 protein (Cdc42/Rac)activated kinase 1 (PAK1), jun B proto-oncogene (JUNB), and Mdm2 p53 binding protein homolog (MDM2) have been discovered in human ovarian cancer using array CGH analysis (Mayr et al., 2006).

Although chicken ovarian cancer is a valuable animal model for studying human ovarian cancer, to our knowledge, there are no reports of $\mathrm{CNV}$ in chicken ovarian cancer. Therefore, we investigated $\mathrm{CNV}$ in chicken ovarian cancer using array CGH analysis.

\section{MATERIALS AND METHODS}

\section{Animals}

The care and experimental use of White Leghorn(WL) chickens were approved by the Institute of Laboratory Animal Resources, Seoul National University, Korea (SNU070823-5). All chickens were maintained under a standard management program at the University Animal Farm, Seoul National University. All procedures used for animal management and reproduction followed the standard operating protocols of our laboratory. The flocks were given free access to feed and water and feed was available for ad libitum consumption. During laying period, chickens were maintained under 16-hour-light per day. To select candidate chickens with ovarian cancer, hen-day egg production of 100 chickens was examined. During the period under investigation, 40 chickens with few egg production were selected for further study.

\section{Samples}

Blood and cancerous ovaries $(n=4)$ from 120-week-old White Leghorn hens were collected for study. Subsets of these samples were frozen for extraction of genomic DNA.

\section{Extraction of genomic DNA}

Genomic DNA was extracted using a DNeasy blood and tissue kit (Qiagen, Hilden, Germany). The purity of the isolated DNA was checked by determining the $A_{260} / A_{280}$ and $\mathrm{A}_{260} / \mathrm{A}_{230}$ ratios using a NanoDrop ND-1000 spectrophotometer (NanoDrop Technologies, DE, USA) according to the instruction manual. The integrity of the genomic DNA was visually inspected on a $1 \%$ agarose gel stained with ethidium bromide (data not shown).

\section{Array $\mathrm{CGH}$ analysis}

For array CGH analysis, a total of $3 \mu \mathrm{g}$ of genomic DNA (1.5 $\mu \mathrm{g}$ each of genomic DNA from blood and ovarian cancer tissue) were labeled using an Invitrogen BioPrime ${ }^{\circledR}$ Array CGH genomic labeling system (Invitrogen, CA, USA). The labeled genomic DNA was hybridized to a NimbleGen Chicken CGH 385K chip (NimbleGen, WI, USA) using a MAUI hybridization system (BioMicro Systems, UT, USA). Imaging and signal data were obtained using a Genepix ${ }^{\circledR}$ 4000B scanner (MDS Analytical Technologies, Ontario, Canada) and NimbleScan 2.5 software (NimbleGen). Probe signal intensities were then analyzed using NimbleScan 2.5 and SignalMap softwares (NimbleGen). DNA copy numbers were determined from the CGH data by a circular binary segmentation algorithm (DNA copy algorithm $\mathrm{v}$ 1.4) of $\mathrm{a}$ NimbleScan program (Olshen et al., 2004).

\section{RESULTS}

\section{Array $\mathrm{CGH}$ analysis}

All White Leghorn chicks were hatched on the same date, maintained for 120 weeks, and then sacrificed to investigate the incidence of ovarian cancer. Because the expanded maintenance of laying hens increases the incidence rate of ovarian cancer (Fredrickson, 1987), 40 reproductively quiescent White Leghorn chickens were examined, and cancerous ovaries were collected from 4 hens. 


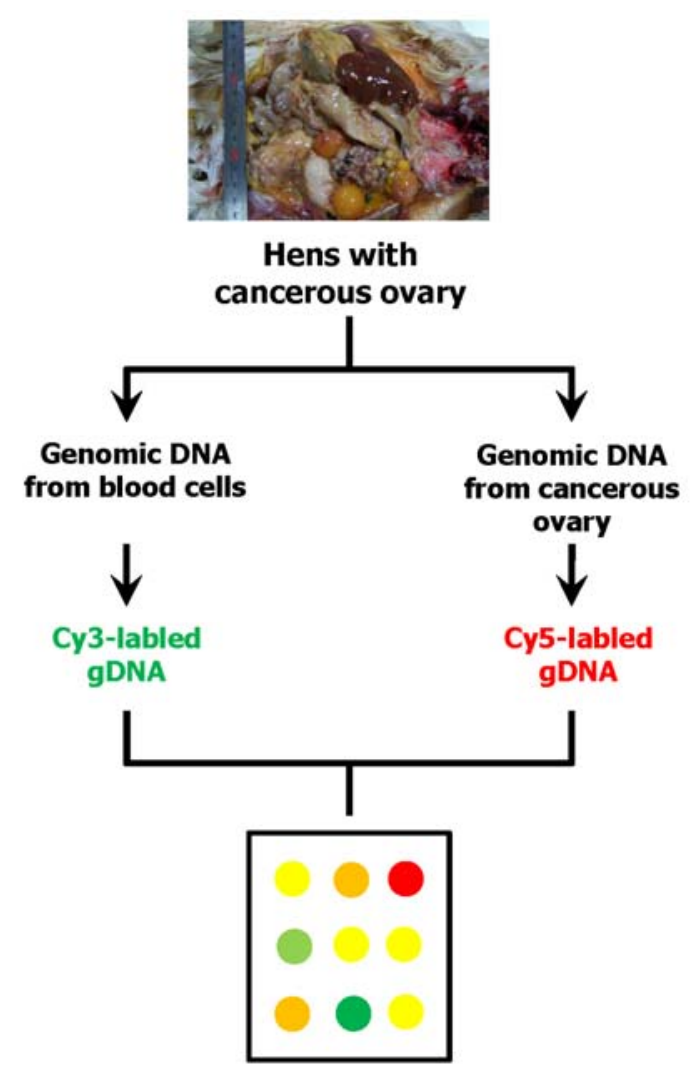

Fig. 1. Experimental design of the array $\mathrm{CGH}$ analysis. Genomic DNA samples from blood cells and ovarian cancer tissues of hens with ovarian cancer were used as control and treatment groups, respectively, in the array $\mathrm{CGH}$ experiment. Cy3- or Cy5-labeled genomic DNA was analyzed using a Nimblegen array CGH chip.

To investigate the potential significance of $\mathrm{CNVs}$ in chicken ovarian cancer (Fig. 1), we isolated genomic DNA from blood cells and ovary tissue of the same hen. To examine the CNV, WUGSC 2.1/galGal3 version of UCSC genome database was subjected to further analysis. The CNV selection criterion was a genomic region indicated by 10 or more successive probes with $\mathrm{a} \pm 0.25$ change in the normalized $\log _{2}$ ratio of the copy number between blood and ovarian cancer. Among the $459 \mathrm{CNV}$ regions found in four chicken ovarian cancers (Fig. 2), the $\mathrm{CNV}$ regions that were detected in more than three cancerous ovaries were significantly selected. As a result, a total of 25 amplified $\mathrm{CNV}$ regions, and no deletion $\mathrm{CNV}$, were found in the genomes of the cancerous ovaries (Table 1). To detect deletion CNV regions, individual ovarian cancers were assayed, and a total of 10 deleted $\mathrm{CNV}$ regions were

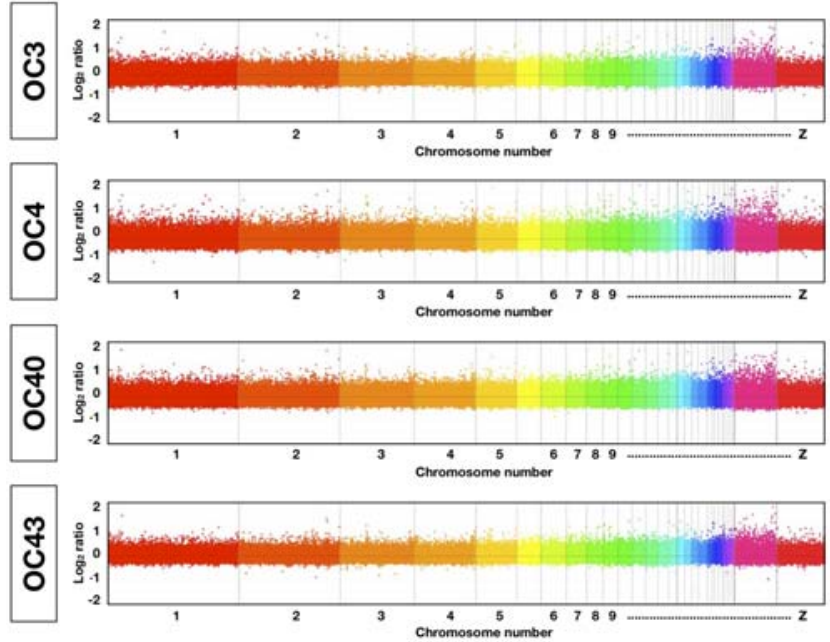

Fig. 2. Array $\mathrm{CGH}$ analysis of chicken ovarian cancer. Four chicken ovarian cancers were used for the array $\mathrm{CGH}$ analysis. Genomic DNA $(3 \mu \mathrm{g})$ from blood cells and cancerous ovary tissues were used as control and treatment groups, respectively, in the array $\mathrm{CGH}$ experiment.

identified in the genomic DNA of cancerous ovaries by comparison with the control blood cell DNA (Table 2). One $\mathrm{CNV}$ was found in each of chromosomes 5, 6, 10, 11, 12, $19,20,25$, and 26, and two or more CNVs were detected in chromosome 3, 7, 8, 9, 14, 18, 22, 24, and 27 (Fig. 3). In our assays, more CNVs were detected in microchromosomes than in macro-chromosomes (Fig. 3). The average sizes of the amplified and deleted CNV regions were $36 \mathrm{~kb}$ and $26 \mathrm{~kb}$, respectively.

\section{Significant CNV regions in chicken ovarian cancer}

To examine the relationship between the genes within the $\mathrm{CNV}$ regions and cancer incidence, the genes located within the 25 amplified and 10 deleted $\mathrm{CNV}$ regions were examined using the UCSC genome browser (http://genome. ucsc.edu), and gene function was investigated using PubMed and Online Mendelian Inheritance in Man (OMIM) databases (Table 1 and 2). Ten amplified regions located in chromosomes 13, 22, 24, 25, 26, and 27 and two deleted regions located in chromosomes 5 and 24 contained cancerrelated protein-coding sequences. To select significant CNVs, we investigated whether the transcriptional regulatory elements and complete gene transcripts were present in the CNVs (Fig. 4). The promoter regions and full transcripts for 12 genes (VIL1, GRK6, ERLIN2, PROSC, GPR124, CKAP2L, 
Table 1. Amplified CNV regions in chicken ovarian cancer

\begin{tabular}{|c|c|c|c|c|c|c|}
\hline Chromosome No. & Start (bp) & End (bp) & Size (bp) & $\begin{array}{l}\text { Genes in the } \\
\text { CNV region }{ }^{\dagger}\end{array}$ & $\begin{array}{l}\text { NCBI Reference } \\
\text { Sequence }\end{array}$ & References \\
\hline 7 & 1385014 & 1422681 & 37667 & No gene & N.A. & \\
\hline 7 & 24052989 & 24115073 & 62084 & $\frac{\text { VIL1, }}{S L C 11 A 1}$ & $\begin{array}{l}\text { NM_205442.1 } \\
\text { NM_204964.1 }\end{array}$ & (Gava et al. 2008) \\
\hline 8 & 24905146 & 24932870 & 27724 & $\begin{array}{l}\text { MIR1562, } \\
\text { NRD1 }\end{array}$ & NM_001031284.1 & \\
\hline 9 & 16527793 & 16587691 & 59898 & No gene & & \\
\hline 10 & 4215023 & 4237745 & 22722 & SCAPER & XM_413736.2 & \\
\hline 11 & 20172743 & 20205037 & 32294 & $B A N P$ & NM_001173545.1 & \\
\hline 12 & 1832557 & 1855044 & 22487 & DOCK3 & XM_414263.2 & \\
\hline 13 & 10210386 & 10260205 & 49819 & $\begin{array}{l}\stackrel{\text { GRK6 }}{S L C 34 A 1} \\
\text { DBN1 } \\
\text { PDLIM7 } \\
\end{array}$ & $\begin{array}{c}\text { XM_414676.2 } \\
\text { XM_425204.2 } \\
\text { NM_205499.1 } \\
\text { NM_001005345.1 }\end{array}$ & $\begin{array}{c}\text { (Mizejewski 1999) } \\
\text { (Krcmery et al. 2010) }\end{array}$ \\
\hline 14 & 2175417 & 2197812 & 22395 & $\begin{array}{c}\text { GET4 } \\
\text { UNC84A }\end{array}$ & $\begin{array}{l}\text { NM_001006159.1 } \\
\text { XM_414757.2 }\end{array}$ & \\
\hline 14 & 14195020 & 14257992 & 62972 & $\mathrm{SOLH}$ & XM_414704.2 & \\
\hline 15 & 12752856 & 12795052 & 42196 & RBM19 & NM_001039268.2 & \\
\hline 18 & 735473 & 760193 & 24720 & $\begin{array}{l}\text { MAP2K4 } \\
\text { MYOCD }\end{array}$ & $\begin{array}{c}\text { XM_415583.2 } \\
\text { NM_001080715.1 }\end{array}$ & \\
\hline 18 & 4455079 & 4507980 & 52901 & $\begin{array}{r}R N F 157 \\
F O X J 1\end{array}$ & $\begin{array}{c}\text { XM_426775.2 } \\
\text { XM_001233326.1 }\end{array}$ & \\
\hline 19 & 652644 & 687922 & 35278 & $\begin{array}{l}\text { WBSCR27 } \\
\text { ABHD11 }\end{array}$ & $\begin{array}{c}\text { XM_001234037.1 } \\
\text { XM_415721.2 }\end{array}$ & \\
\hline 20 & 3795015 & 3830501 & 35486 & $\begin{array}{l}\text { PPP1R16B } \\
\text { FAM83D } \\
\text { DHX35 }\end{array}$ & $\begin{array}{c}\text { NM_001030851.1 } \\
\text { XM_417351.2 } \\
\text { XM_417352.2 }\end{array}$ & \\
\hline 22 & 432714 & 462728 & 30014 & $\begin{array}{c}\text { PRNP } \\
\text { RASSF2 } \\
\end{array}$ & $\begin{array}{c}\text { NM_205465.1 } \\
\text { NM_001030884.1 }\end{array}$ & $\begin{array}{l}\text { (Underhill-Day et al. } \\
\text { 2011) }\end{array}$ \\
\hline 22 & 2202665 & 2252857 & 50192 & $\begin{array}{l}\frac{\text { ERLIN2 }}{\text { PROSC }} \\
\text { GPR124 } \\
\end{array}$ & $\begin{array}{l}\text { XM_424380.2 } \\
\text { XM_424381.2 } \\
\text { XR_027045.1 }\end{array}$ & (Williams et al. 2010) \\
\hline 22 & 3860262 & 3890050 & 29788 & $\begin{array}{c}\overline{C K A P 2 L} \\
\underline{\underline{\mathbf{L 1 B}}} \\
\underline{\mathbf{Y K T 6}}\end{array}$ & $\begin{array}{c}\text { XM_424317.2 } \\
\text { NM_204524.1 } \\
\text { NM_001113744.1 }\end{array}$ & (Kluger et al. 2004) \\
\hline 24 & 1882879 & 1927965 & 45086 & $\begin{array}{l}\overline{\text { THY1 }} \\
\overline{M I R 1466} \\
\text { USP2 }\end{array}$ & $\begin{array}{l}\text { NM_204381.1 } \\
\text { NM_204926.1 }\end{array}$ & $\begin{array}{l}\text { (Abeysinghe et al. 2003) } \\
\text { (Stevenson et al. 2007) }\end{array}$ \\
\hline 24 & 4202977 & 4225354 & 22377 & $\overline{\overline{N T M}}$ & NM_204711.1 & (Ntougkos et al. 2005) \\
\hline 25 & 1467993 & 1492906 & 24913 & $\begin{array}{l}\text { UBAP2L } \\
\text { SHC1 } \\
\text { MIR3536 } \\
\text { MIR1629 }\end{array}$ & $\begin{array}{l}\text { XM_423817.2 } \\
\text { XM_424373.2 }\end{array}$ & (Lucs et al. 2010) \\
\hline 26 & 640262 & 672698 & 32436 & $\frac{\text { CSRP1 }}{P P P 1 R 12 B}$ & $\begin{array}{l}\text { NM_205248.1 } \\
\text { NM_204727.1 }\end{array}$ & (Zhou et al. 2008) \\
\hline 27 & 1575446 & 1597678 & 22232 & A2ML1 & XM_416480.2 & \\
\hline 27 & 3362564 & 3395492 & 32928 & PHOSPHO1 & NM_204845.1 & \\
\hline 27 & 3962872 & 3987989 & 25117 & LASP1 & NM_001177329.1 & (Dimova et al. 2009) \\
\hline
\end{tabular}

${ }^{\dagger}$ The cancer-related genes are marked as underlined and bold characters. 
Table 2. Deleted CNV regions in chicken ovarian cancer

\begin{tabular}{|c|c|c|c|c|c|c|}
\hline Chromosome No. & Start (bp) & End (bp) & Size (bp) & $\begin{array}{l}\text { Genes in the } \\
\text { CNV region }\end{array}$ & $\begin{array}{l}\text { NCBI Reference } \\
\text { Sequence }\end{array}$ & References \\
\hline 3 & 3590164 & 3617944 & 27780 & No gene & & \\
\hline 3 & 31567927 & 31600030 & 32103 & TMEM63B & XM_419493.2 & \\
\hline 5 & 25290498 & 25317943 & 27445 & $\begin{array}{c}\text { ACP2 } \\
\text { DDB2 } \\
\text { PACSIN3 }\end{array}$ & $\begin{array}{c}\text { NM_001031548.1 } \\
\text { NM_001039301.1 } \\
\text { DQ508438.1 }\end{array}$ & (Stoyanova et al. 2009) \\
\hline 6 & 5400234 & 5435312 & 35078 & TSPAN14 & NM_001031218.1 & \\
\hline 8 & 14060387 & 14082555 & 22168 & ALG14 & XM_430156.2 & \\
\hline 9 & 17305474 & 17327735 & 22261 & $\begin{array}{c}\text { RFC4 } \\
\text { MCF2L2 }\end{array}$ & $\begin{array}{c}\text { NM_001006550.1 } \\
\text { XM_422768.2 }\end{array}$ & \\
\hline 12 & 8905189 & 8932573 & 27384 & DNAH7 & XR_027197.1 & \\
\hline 18 & 4737987 & 4760284 & 22297 & SAP30BP & XM_415631.2 & \\
\hline 18 & 10072784 & 10102512 & 29728 & $\begin{array}{l}\text { LUC7L3 } \\
\text { ANKRD40 }\end{array}$ & $\begin{array}{l}\text { NM_001031530.1 } \\
\text { NM_001031531.1 }\end{array}$ & \\
\hline 24 & 3792842 & 3817736 & 24894 & ARHGEF12 & XM_417890.2 & (Ong et al. 2009) \\
\hline
\end{tabular}

${ }^{\dagger}$ The cancer-related genes are marked as underlined and bold characters.

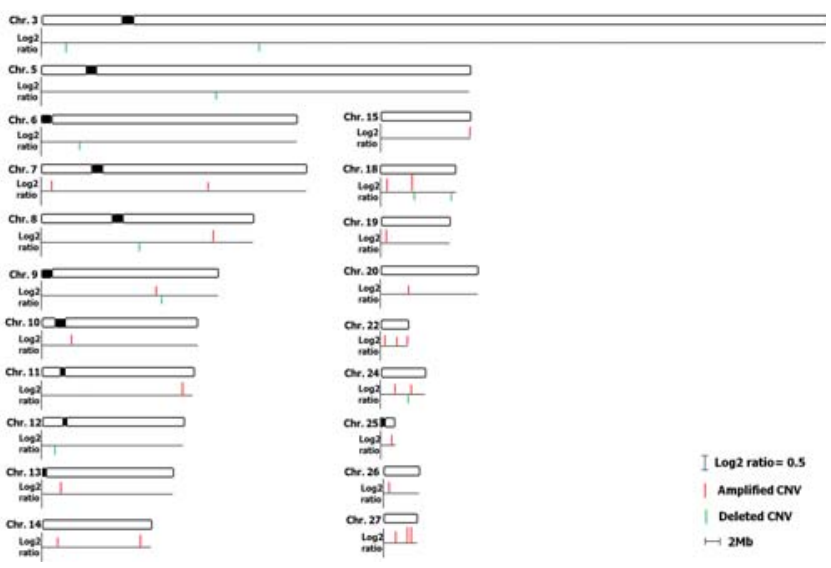

Fig. 3. Positions of CNVs detected in each chromosome. Chromosome size is relative based on information from the UCSC genome database (http://genome.ucsc.edu/). Scale bar $=2 \mathrm{Mb}$. The black box in the chromosome indicates the centromere. Information is not currently available for centromeres of chromosomes 14, 15, 20, $19,20,22,26$, and 27. Vertical red and green lines denote amplified and deleted CNVs, respectively. Scale bar $=0.5$, as $\log _{2}$ ratio for alteration levels of CNVs.

IL1B, YKT6, THY1, USP2, SHC1, and LASP1) and partial exons and introns of three genes(RASSF2, NTM, and CSRP1) were included in the amplified CNV regions. Interestingly, three miRNA sequences (MIR1466, MIR3536, and MIR1629) were also amplified in the chicken ovarian tumors. Deleted CNV regions contained the promoter regions and full transcripts for the genes ARHGEF12, ACP2, and DDB2.

\section{DISCUSSION}

Based on several studies, CNV is a hallmark of cancerous cells (Shlien and Malkin, 2009). Both common and rare CNV regions may contribute to the development of cancer, and studies on $\mathrm{CNV}$ will be helpful for the treatment and chemoprevention of human ovarian cancer. To date, most investigations of $\mathrm{CNV}$ have been conducted using established cancer cell lines (Feuk et al., 2006; Grunewald et al., 2006; Dimova et al., 2009) because of difficulties in obtaining fresh human cancerous tissues. To allow in vivo studies, suitable animal models have been utilized. In the present study, we used chickens as an animal model of human ovarian cancer and investigated $\mathrm{CNV}$ in the cancerous ovaries of four chickens.

Amplification and deletion of chromosomal segments are two types of structural variations in genomic DNA, and both are related to several biological phenomena. Changes in the copy number of genomic regions containing protein-coding or promoter sequences can alter the expression of genes in the region. Some of these alterations are closely associated with the predisposition, incidence, and progression of cancer (Hastings et al., 2009). Investigating CNV in chicken ovarian cancer may provide meaningful information for comparative studies of human and chicken ovarian cancer. 


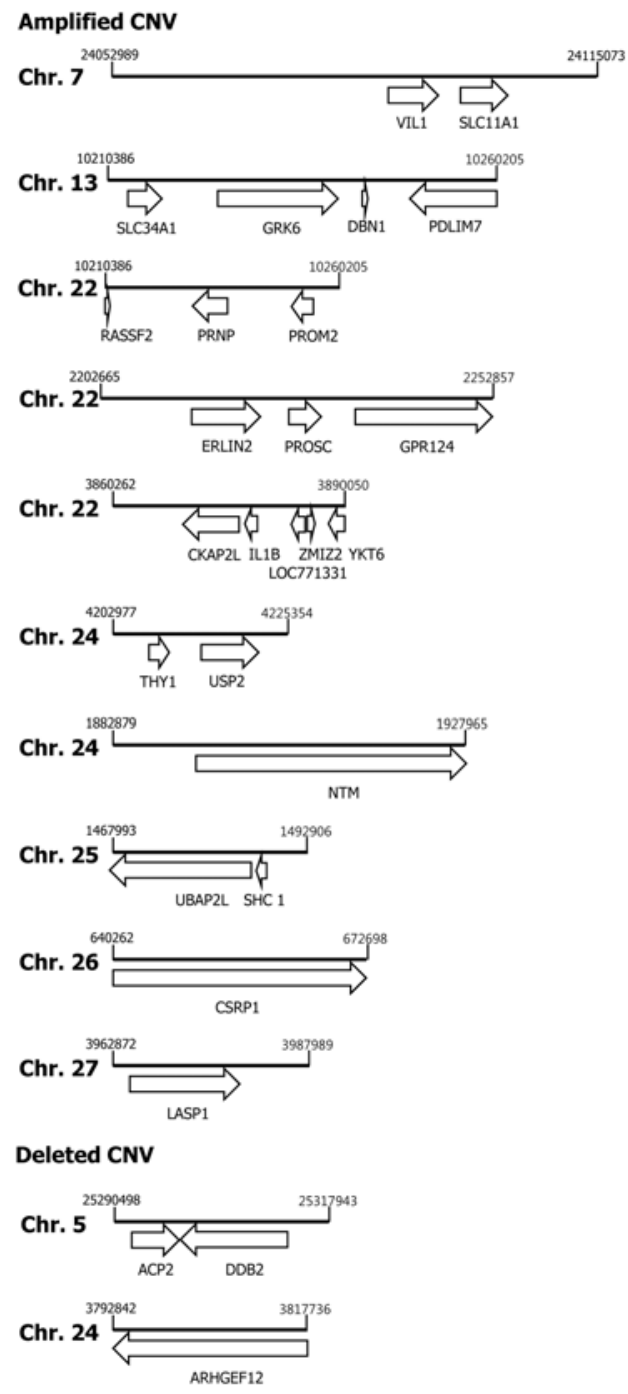

Fig. 4. Cancer-related genes located in CNVs. The arrow and its direction indicate the gene transcript and its orientation, respectively. Transcript and CNV sizes are based on information from the UCSC genome database. Scale bar $=10$ $\mathrm{kb}$.

Here, we detected 25 amplified and 10 deleted CNVs in chicken ovarian cancer. The 25 amplified regions were simultaneously detected in the ovarian cancer tissues from at least three chickens, whereas the deleted CNVs were identified in individual chickens. Our difficulty in finding common deleted $\mathrm{CNV}$ regions may be attributable to the small sample number. Nevertheless, ours is the first study on CNVs in chicken ovarian cancer, and this knowledge may contribute to a better understanding of human ovarian cancer.

The CNV regions identified in chicken ovarian cancer in the present study contained genes related to cancer development in humans. Generally, the upregulation of gene expression by amplification of a genomic segment influences carcinogenesis in normal tissues (Feuk et al., 2006). The amplified CNV genomic region between 220266 and 2252857 of the chicken chromosome 12 contains the loci for ERLIN2, PROSC, and GPR124, which correspond to human chromosome 8p. This region has been reported to be amplified or deleted in urothelial carcinoma and other epithelial cancers (Williams et al., 2010). Interleukin 1 (IL1), which is contained in an amplified region in our study, is involved in the carcinogenesis of several cancers (Hefler et al., 2002; Sehouli et al., 2002; Hefler et al., 2005), and it appears to increase the proliferative activity of ovarian cancer and enhance cytotoxicity (Hefler et al., 2002; Ioana Braicu et al., 2007). Additionally, the YKT6 gene, which is localized near $I L 1 B$, has been reported to play an important role in tumor invasion and metastasis (Kluger et al., 2004). Therefore, amplified regions involving IL1B and YKT6 may be associated with cancer development in the chicken ovary. In addition, $\mathrm{CNV}$ regions containing the SHC1 gene are associated with tumorigenesis, as SHC is necessary for the inhibition of apoptosis, cell proliferation, and cell polarity destruction regulated by ERBB2 signaling (Lucs et al., 2010). Finally, LASP1, whose gene is located between 3,962,872 and $3,987,989$ on chicken chromosome 27 , is an actinbinding protein involved in peripheral cell extensions of epithelial cancer cells (Schreiber et al., 1998), and its inhibition disturbs the proliferation and migration of breast cancer cells (Grunewald et al., 2006). Based on array CGH analysis of human ovarian cancer, LASP1 is a strong candidate for an inducer of ovarian tumorigenesis (Dimova et al., 2009).

In conclusion, we investigated $\mathrm{CNV}$ regions in chicken ovarian cancer. Several amplified or deleted regions were detected in ovarian cancer tissue DNA, and some of these regions contained promoter regions or transcripts of cancerrelated genes. Our results may be meaningful for comparative studies between human ovarian cancer and chicken models of ovarian cancer and may provide insights into the cause of ovarian cancer.

\section{ACKNOWLEDGEMENTS}

The authors thank Dr. Chul-Hong Kim (Theragen Co., Ltd.) for manuscript preparation and helpful discussions. This work was supported by Engineering Foundation (KOSEF) grant (2007-0055871), World Class University program (R31-10056) 
through the KOSEF funded by the National Research Foundation of Korea and the Ministry of Education, Science and Technology, Korea.

\section{REFERENCES}

Abeysinghe, H. R., Cao, Q., Xu, J., Pollock, S., Veyberman, Y., Guckert, N. L., Keng, P. and Wang, N. 2003. THY1 expression is associated with tumor suppression of human ovarian cancer. Cancer Genet Cytogenet. 143(2):125-132.

Ahn, S. E., Choi, J. W., Rengaraj, D., Seo, H. W., Lim, W., Han, J. Y. and Song, G. 2010. Increased expression of cysteine cathepsins in ovarian tissue from chickens with ovarian cancer. Reprod Biol Endocrinol. 8:100.

Dimova, I., Orsetti, B., Negre, V., Rouge, C., Ursule, L., Lasorsa, L., Dimitrov, R., Doganov, N., Toncheva, D. and Theillet, C. 2009. Genomic markers for ovarian cancer at chromosomes 1 , 8 and 17 revealed by array CGH analysis. Tumori. 95(3): 357-366.

Feuk, L., Carson, A. R. and Scherer, S. W. 2006. Structural variation in the human genome. Nat Rev Genet. 7(2):85-97.

Fredrickson, T. N. 1987. Ovarian tumors of the hen. Environ Health Perspect. 73:35-51.

Gava, N., C, L. C., Bye, C., Byth, K. and deFazio, A. 2008. Global gene expression profiles of ovarian surface epithelial cells in vivo. J Mol Endocrinol. 40(6):281-296.

Grunewald, T. G., Kammerer, U., Schulze, E., Schindler, D., Honig, A., Zimmer, M. and Butt, E. 2006. Silencing of LASP-1 influences zyxin localization, inhibits proliferation and reduces migration in breast cancer cells. Exp Cell Res. 312(7): 974-982.

Hastings, P. J., Lupski, J. R., Rosenberg, S. M. and Ira, G. 2009. Mechanisms of change in gene copy number. Nat Rev Genet. 10(8):551-564.

Hefler, L. A., Grimm, C., Lantzsch, T., Lampe, D., Leodolter, S., Koelbl, H., Heinze, G., Reinthaller, A., Tong-Cacsire, D., Tempfer, C. and Zeillinger, R. 2005. Interleukin-1 and interleukin- 6 gene polymorphisms and the risk of breast cancer in caucasian women. Clin Cancer Res. 11(16):5718-5721.

Hefler, L. A., Ludwig, E., Lebrecht, A., Zeillinger, R., TongCacsire, D., Koelbl, H., Leodolter, S. and Tempfer, C. B. 2002. Polymorphisms of the interleukin-1 gene cluster and ovarian cancer. J Soc Gynecol Investig. 9(6):386-390.

Ioana Braicu, E., Mustea, A., Toliat, M. R., Pirvulescu, C., Konsgen, D., Sun, P., Nurnberg, P., Lichtenegger, W. and Sehouli, J. 2007. Polymorphism of IL-1alpha, IL-1beta and
IL-10 in patients with advanced ovarian cancer: results of a prospective study with 147 patients. Gynecol Oncol. 104(3): 680-685.

Jackson, E., Anderson, K., Ashwell, C., Petitte, J. and Mozdziak, P. E. 2007. CA125 expression in spontaneous ovarian adenocarcinomas from laying hens. Gynecologic Oncology. 104(1):192-198.

Johnson, K. A. 2009. The Standard of Perfection: Thoughts about the Laying Hen Model of Ovarian Cancer. Cancer Prevention Research. 2(2):97-99.

Kim, S. W., Kim, J. W., Kim, Y. T., Kim, J. H., Kim, S., Yoon, B. S., Nam, E. J. and Kim, H. Y. 2007. Analysis of chromosomal changes in serous ovarian carcinoma using highresolution array comparative genomic hybridization: Potential predictive markers of chemoresistant disease. Genes Chromosomes Cancer. 46(1):1-9.

Kluger, H. M., Kluger, Y., Gilmore-Hebert, M., DiVito, K., Chang, J. T., Rodov, S., Mironenko, O., Kacinski, B. M., Perkins, A. S. and Sapi, E. 2004. cDNA microarray analysis of invasive and tumorigenic phenotypes in a breast cancer model. Lab Invest. 84(3):320-331.

Krcmery, J., Camarata, T., Kulisz, A. and Simon, H. G. 2010. Nucleocytoplasmic functions of the PDZ-LIM protein family: new insights into organ development. Bioessays. 32(2):100108.

Lucs, A. V., Muller, W. J. and Muthuswamy, S. K. 2010. Shc is required for ErbB2-induced inhibition of apoptosis but is dispensable for cell proliferation and disruption of cell polarity. Oncogene. 29(2):174-187.

Mayr, D., Kanitz, V., Anderegg, B., Luthardt, B., Engel, J., Lohrs, U., Amann, G. and Diebold, J. 2006. Analysis of gene amplification and prognostic markers in ovarian cancer using comparative genomic hybridization for microarrays and immunohistochemical analysis for tissue microarrays. Am J Clin Pathol. 126(1):101-109.

Mizejewski, G. J. 1999. Role of integrins in cancer: survey of expression patterns. Proc Soc Exp Biol Med. 222(2):124-138.

Ntougkos, E., Rush, R., Scott, D., Frankenberg, T., Gabra, H., Smyth, J. F. and Sellar, G. C. 2005. The IgLON family in epithelial ovarian cancer: expression profiles and clinicopathologic correlates. Clin Cancer Res. 11(16):5764-5768.

Ong, D. C., Ho, Y. M., Rudduck, C., Chin, K., Kuo, W. L., Lie, D. K., Chua, C. L., Tan, P. H., Eu, K. W., Seow-Choen, F., Wong, C. Y., Hong, G. S., Gray, J. W. and Lee, A. S. 2009. LARG at chromosome 11q23 has functional characteristics of a tumor suppressor in human breast and colorectal cancer. 
Oncogene. 28(47):4189-4200.

Orsulic, S. 2004. Ovarian Cancer. In: Holland, E. C. (Ed.), Mouse Models of Human Cancer. Whiley-Liss, Inc., New Jersey, pp. 171-187.

Rodriguez-Burford, C., Barnes, M. N., Berry, W., Partridge, E. E. and Grizzle, W. E. 2001. Immunohistochemical expression of molecular markers in an avian model:a potential model for preclinical evaluation of agents for ovarian cancer chemoprevention. Gynecol Oncol. 81(3):373-379.

Schreiber, V., Moog-Lutz, C., Regnier, C. H., Chenard, M. P., Boeuf, H., Vonesch, J. L., Tomasetto, C. and Rio, M. C. 1998. Lasp-1, a novel type of actin-binding protein accumulating in cell membrane extensions. Mol Med. 4(10): 675-687.

Sehouli, J., Mustea, A., Konsgen, D., Katsares, I. and Lichtenegger, W. 2002. Polymorphism of IL-1 receptor antagonist gene: role in cancer. Anticancer Res. 22(6A):34213424.

Seo, H. W., Park, J. Y., Lee, H. C., Kim, D., Song, Y. S., Lim, J. M., Song, G. and Han, J. Y. 2009. Physiological Effects of Diethylstilbestrol Exposure on the Development of the Chicken Oviduct. J Anim Sci \& Technol. 51(6):485-492.

Shlien, A. and Malkin, D. 2009. Copy number variations and cancer. Genome Med. 1(6):62.
Stevenson, L. F., Sparks, A., Allende-Vega, N., Xirodimas, D. P., Lane, D. P. and Saville, M. K. 2007. The deubiquitinating enzyme USP2a regulates the p53 pathway by targeting Mdm2. EMBO J. 26(4):976-986.

Stoyanova, T., Roy, N., Kopanja, D., Bagchi, S. and Raychaudhuri, P. 2009. DDB2 decides cell fate following DNA damage. Proc Natl Acad Sci U S A. 106(26):10690-10695.

Underhill-Day, N., Hill, V. and Latif, F. 2011. N-terminal RASSF family (RASSF7-RASSF10): A mini review. Epigenetics. 6(3): 11-19.

Vanderhyden, B. C., Shaw, T. J. and Ethier, J. F. 2003. Animal models of ovarian cancer. Reprod Biol Endocrinol. 1:67.

Williams, S. V., Platt, F. M., Hurst, C. D., Aveyard, J. S., Taylor, C. F., Pole, J. C., Garcia, M. J. and Knowles, M. A. 2010. High- resolution analysis of genomic alteration on chromosome arm 8p in urothelial carcinoma. Genes Chromosomes Cancer. 49 (7):642-659.

Zhou, C. Z., Qiu, G. Q., Wang, X. L., Fan, J. W., Tang, H. M., Sun, Y. H., Wang, Q., Huang, F., Yan, D. W., Li, D. W. and Peng, Z. H. 2008. Screening of tumor suppressor genes on 1q31.1-32.1 in Chinese patients with sporadic colorectal cancer. Chin Med J (Engl). 121(24):2479-2486.

(Received Nov. 16, 2010; Revised Dec. 8, 2010; Accepted Dec. 13, 2010) 